\title{
POLA PERJALANAN DAN PENGELUARAN WISATAWAN MILENIAL KE BALI
}

\author{
LGLK. Dewi ${ }^{1}$ \\ ${ }^{1}$ Email: leli_ipw@unud.ac.id \\ Program Studi Industri Perjalanan Wisata, Fakultas Pariwisata, Universitas Udayana
}

\begin{abstract}
The trend of world tourism, especially in the dimension of tourists as travelers. The current phenomenon is that millennial tourists are the most potential types of tourists for Bali tourism at this time. Bali as a central tourist area in Indonesia, and world tourist destinations have the potential to support tourism growth. These potentials include human potential and culture. Beautiful and ideal natural panorama, green forests, mountains, lakes, rivers and rice fields that stretch with terraces and beautiful beaches with a variety of black and white sand. This study aims to determine the trend of millennial tourist trips during their trips in Bali and to find out the travel patterns and spending patterns of millennial tourists during their tour activities in Bali. This study uses descriptive qualitative-quantitative data analysis (mix method). The sample was determined purposively amounting to 100 millennial tourists who traveled to Bali. Data collection techniques are observation, questionnaires, and documentation. The study results show that the pattern of millennial tourists traveling to Bali is that the millennial tourists are tourists who have come more than once, with trips dominated by airplanes to Bali, in their activities tourists prefer social media as a source of information, preferring to take selfies on tourist attraction, use a private rental vehicle. Millennial tourists spending patterns, dominated by accommodation, souvenirs, attractions, rental vehicles and food and beverages. In the selection of accommodation, attractions and food and drinks are more influenced by social media which is the source of his recommendations.
\end{abstract}

\begin{abstract}
Abstrak: Trend pariwisata dunia khususnya pada dimensi wisatawan sebagai pelaku perjalanan mengalami perubahan yang cukup mengejutkan. Fenomena saat ini yaitu wisatawan milenial merupakan jenis wisatawan yang paling potensial bagi pariwisata Bali pada saat ini. Bali sebagai daerah pusat wisata Indonesia bagian tengah, dan tujuan wisata dunia memeiliki potensi yang menunjang pertumbuhan kepariwisataan. Potensi tersebut antara lain mencakup potensi manusia dan kebudayaannya. Panorama alam yang indah dan ideal, hutan yang hijau, gunung, danau, sungai serta sawah yang membentang dengan teras-teras serta pantai yang indah dengan beragam pasir hitam dan putih. Oleh karena itu studi ini bertujuan untuk mengetahui trend perjalanan wisata wisatawan milenial selama mereka berwisata di Bali serta untuk mengetahui pola perjalanan dan pola pengeluaran wisatawan milenial selama mereka melakukan kegiatan wisata di Bali. Studi ini menggunakan analisis data deskriptif kualitatif-kuantitatif (mix method). Sampel ditentukan secara purposive berjumlah 100 orang wisatawan milenial yang berwisata ke Bali. Teknik pengumpulan data dilakukan dengan cara observasi, kuesioner, dan dokumentasi. Hasil studi menunjukkan bahwa pola perjalanan wisatawan milenial ke Bali adalah bahwa wisatawan milenial tersebut adalah wisatawan yang datang sudah lebih dari sekali, dengan perjalanan yang didominasi menggunakan pesawat terbang menuju Bali, dalam beraktivitas wisatawan lebih memilih media sosial sebagai sumber informasi, lebih suka melakukan selfie pada daya tarik wisata, menggunakan kendaraan sewa pribadi. Pola pengeluaran wisatawan milenial, didominasi oleh akomodasi, souvenir, Atraksi, kendaraan sewa serta makanan dan minuman. Dalam pemilihan akomodasi, atraksi dan makanan serta minuman lebih banyak dipengaruhi oleh media sosial yang menjadi sumber rekomendasinya.
\end{abstract}

Keywords: bali, millennial tourist, spending pattern, travel pattern. 


\section{PENDAHULUAN}

Trend pariwisata dunia khususnya pada dimensi wisatawan sebagai pelaku perjalanan mengalami perubahan yang cukup mengejutkan. Dimulai pada awal tahun 2015 sampai saat ini trend wisatawan yang mendominasi perjalanan wisata di seluruh dunia adalah wisatawan milenial.

Wisatawan milenial adalah sebutan untuk wisatawan yang lahir pada tahun 19802000, jadi jika dilihat berdasarkan pada umur wisatawan, wisatawan milenial adalah wisatawan yang berumur 18 tahun sampai dengan 38 tahun. Mereka disebut sebagai wisatawan milenial karena mereka terlahir pada era milenium, dimana kehidupan mereka sudah melekat dengan kemajuan dan perkembangan teknologi yang menyebabkan segala sesuatunya harus diperoleh secara instant. Wisatawan milenial merupakan wisatawan yang memiliki potensi yang sangat besar bagi pariwisata dunia, hal ini dapat terjadi karena umur mereka yang masih produktif dan populasi mereka yang banyak di seluruh dunia.

Dilansir pada salah satu media daring/online dikatakan oleh PBB bahwa sebesar 20\% wisatawan dunia berasal dari wisatawan milenial. Wisatawan milenial ini memiliki cara tersendiri saat melakukan kegiatan wisata, mereka cenderung melakukan perjalanan wisata secara spontan, tidak memerlukan banyak waktu untuk perencanaan dan percaya pada ulasan-ulasan destinasi wisata di internet terutama media sosial (www.travel.kompas.com). Wisatawan milenial adalah wisatawan yang unik dan sangat konsumtif. Seperti yang diberitakan oleh salah satu majalah bisnis online yaitu www.surabaya.bisnis.com, Senin, 07 Maret 2016 dalam sebuah artikel bertajuk Perilaku Konsumen Generasi Milenial Menabung demi Hal Konsumtif, disebutkan bahwa berdasarkan pada riset yang dilakukan oleh lembaga independen Provetic tentang perilaku belanja konsumen menunjukkan bahwa para generasi milenial cenderung memiliki perilaku menabung untuk hal-hal yang bersifat konsumtif seperti membeli tiket konser musik ataupun untuk berwisata.

Bali sebagai salah satu destinasi wisata favorit di dunia, sudah sepantasnya menggarap serius potensi dari wisatawan milenial, khususnya wisatawan milenial nusantara. Wisatawan milenial nusantara tidak dapat dipandang dengan sebelah mata, karena jumlah populasi mereka dan sifat konsumtif yang mereka miliki cukup tinggi. Hal ini merupakan peluang bagi para stake holder pariwisata Bali supaya mampu menyediakan sarana dan prasarana pariwisata yang sesuai dengan karakteristik wisatawan milenial.

Jika berbicara mengenai potensi wisatawan nusantara (wisnus) khususnya dalam hal pengeluaran mereka selama berwisata di Bali, maka berdasarkan pada analisa "Buku Pasar Wisatawan Nusantara 2015" dalam database Dinas Pariwisata Bali yang dilansir online pada www.etnikbali.com (diunduh Minggu, 21 Januari 2017, pk. 19.18 WITA), disebutkan bahwa jumlah pengeluaran rata-rata per hari diketahui bahwa wisnus mengunjungi Bali dengan pengeluaran diatas Rp. 1.000.000. Data ini menunjukkan bahwa wisnus adalah pasar yang sangat potensial bagi Bali. Masih berdasarkan pada analisa "Buku Pasar Wisatawan Nusantara 2015" dikemukakan bahwa wisnus yang datang berkunjung ke Bali didominasi oleh usia 26-55 tahun sebanyak 60,8\% dan kelompok usia 1625 tahun sebanyak 31,2\%. Data ini memperkuat bahwa wisnus yang datang berkunjung ke Bali adalah merupakan wisatawan milenial.

Studi mengenai wisatawan khususnya wisatawan milenial nusantara, belum banyak dilakukan. Terdapat penelitian yang mengangkat wisatawan milenial sebagai subjek penelitian yang dihubungkan dengan keputusan pembelian pada industri kuliner. Penelitian ini dilakukan oleh Rimandiyanta dkk (2017) mengangkat permasalahan mengenai faktor - faktor yang mempengaruhi keputusan pembelian pada industri kuliner diketahui bahwa wisatawan milenial bahwa store atmosphere dan store image berpengaruh secara signifikan dalam keputusan pembelian oleh generasi milenial pada industri kuliner di Kota Tasikmalaya.

Berdasarkan pada fenomena trend perjalanan wisata yang dikuasai wisatawan milenial, keunikan karakteristik wisatawan milenial yang gemar merencanakan perjalanan wisata secara individu, serta sifat konsumtif yang dimiliki, serta banyaknya jumlah kunjungan wisnus yang masuk dalam rentang kelompok wisatawan milenial membuat peneliti tertarik untuk mengangkat topik mengenai Pola Perjalanan dan Pola Pengeluaran Wisatawan Milenial Nusantara 
Berwisata di Bali. Hasil dari studi ini nantinya diharapkan dapat memberikan informasi kepada seluruh stake holder pariwisata Bali sehingga semua stake holder pariwisata Bali siap dan mampu mengelola potensi wisatawan milenial nusantara seoptimal mungkin sehingga memberikan dampak yang positif dan membangun bagi perkembangan kepariwisataan Bali di masa yang akan datang.

\section{METODE}

Studi ini dilakukan untuk mengetahui pola perjalanan dan pola pengeluaran wisatawan milenial dalam berkunjung ke Bali. Variabel yang digunakan adalah variabel pola perjalanan dengan indikator trip descriptor dan variabel pola pengeluaran dengan indikator pengeluaran konsumsi akhir.

Untuk mendapatkan data dalam studi ini digunakan beberapa teknik pengumpulan data antara lain: observasi, penyebaran kuisioner, dan dokumentasi.

Teknik penentuan sampel wisatawan pada studi ini dilakukan secara purposive. Sedangkan untuk teknik pengambilan sampel dilakukan secara accidental. Studi ini menggunakan kuisioner yang dibagikan kepada 100 orang wisatawan milenial nusantara yang kebetulan ditemui saat menyebaran kuisioner di beberapa daya tarik wisata populer di Kawasan Wisata Kuta Bali.

Teknik Analisis data yang digunakan dalam studi ini adalah deskriptif kualitatifkuantitatif (mix method). studi deskriptif ini dimaksudkan untuk mengeksplorasi dan mengklarifikasi suatu fenomena atau kenyataan sosial dengan cara mendeskripsikan sejumlah variabel yang berkenaan dengan masalah dan unit yang diteliti (Faisal, 2001:20). studi ini dimaksudkan untuk mengeksplorasi dan mengklarifikasi mengenai pola perjalanan, pola pengeluaran wisatawan milenial nusantara berwisata di Bali. Untuk penyajian data dilakukan dalam bentuk uraian singkat, bagan, dan tabel. Pengolahan data secara kuantitatif dilakukan khususnya mengenai permasalahan pola perjalanan dan pengeluaran wisatawan perjalanan dan wisatawan yang akan mempergunakan bantuan skala likert dengan skala 5 dimana setiap jawaban memiliki nilai antara 1 sampai 5 . Pembobotan ini digunakan guna mengetahui rangking atau prioritas daya tarik yang dikunjungi oleh wisatawan milenial tersebut, serta indikator yang mendominasi pengeluaran wisatawan milenial nusantara, dan rata-rata pengeluaran wisatawan milenial per harinya.

\section{HASIL DAN PEMBAHASAN}

Propinsi Bali merupakan salah satu dari 33 Propinsi yang ada di Indonesia. Propinsi Bali terdiri dari Pulau Bali, Pulau Nusa Penida serta beberapa Pulau-pulau kecil lainnya memiliki luas wilayah 5.632,82 kilometer persegi. Secara administrasi Pulau Bali terdiri dari delapan Kabupaten, satu wilayah kota, 53 kecamatan dan memiliki 658 Desa/Kelurahan, serta terdapat 3563 Banjar/Dusun/lingkungan. Bali sebagai daerah pusat wisata Indonesia bagian tengah, dan tujuan wisata dunia memeiliki potensi yang menunjang pertumbuhan kepariwisataan. Potensi tersebut antara lain mencakup potensi manusia dan kebudayaannya. Panorama alam yang indah dan ideal, hutan yang hijau, gunung, danau, sungai serta sawah yang membentang dengan teras-teras serta pantai yang indah dengan beragam pasir hitam dan putih. Perpaduan alam, manusia dan kebudayaan Bali yang unik yang berlandaskan kepada konsepsi keserasian mewujudkan satu kondisi estetika yang ideal dan bermutu tinggi.

\section{Karakteristik Wisatawan Milenial}

Dari 200 sampel menunjukkan bahwa Usia wisatawan milenial dalam rentang 0-20 tahun : 80 orang (40\%), 21-30 tahun : 96 orang (48\%), 31-40: 24 orang (24\%). Maka dari itu kita ketahui bahwa yang dikatakan usia milenial adalah usia dengan tahun kelahiran antara 1980 hingga 2000 dengan kisaran usia 18-38 tahun. Dan diketahui bahwa karakteristik usia yang mendominasi datang ke Bali pada rentang usia wisatawan milenial adalah Usia 21-30 tahun. Untuk daerah asal wisatawan dari 200 orang yang dijadikan responden dengan cara pengambilan sampel acak diperoleh hasil bahwa lebih didominasi oleh wisatawan domestik 174 orang (87\%) dibandingkan dengan wisatawan mancanegara 26 orang (13\%).

Diketahui berasarakan jenis kelamin dari 200 responden untuk pria 65 orang $(65 \%)$ dan wanita 35 orang $(35 \%)$. Dapat dilihat bahwa wisatawan milenial didominasi oleh pria. Untuk status perkawinan wisatawan milenial ke Bali lebih didominasi oleh wisatawan yang berstatus belum kawin sebanyak 79 (79\%) dan sudah kawin 21 orang (21\%). Dilihat dari rentang usia pada Tabel 5 
diatas bahwa dalam pendidikan wisatawan milenial ke Bali didominasi oleh SMA 38 orang (38\%), S1 33 orang (33\%), S2 7 orang $(3.5 \%)$.

Untuk jenis pekerjaan didominasi oleh pelajar dan mahasiswa sejumlah 108 orang (54\%), PNS 6 orang (3\%), Swasta/Profesional 76 orang $(38 \%)$, dan lainnya 10 orang $(5 \%)$. Untuk pendapatan wisatawan didominasi oleh pendapatan dibawah satu juta sejumlah 98 orang (49\%), jika dikaitkan dengan pekerjaan wisatawan adalah mayoritas pelajar/mahasiswa masih dibawah tanggungan orang tua. Kemudian penghasilan diatas tiga juta juga cukup banyak sejumlah 64 orang (32\%) dan terakhir pendapatan antara satu juta sampai tiga juta 38 orang (19\%). Untuk jumlah anggota keluarga yang diajak berlibur ke Bali lebih didominasi oleh 2-3 orang anggota keluarga dengan jumlah responden 79 $(39,5 \%)$, berikutnya satu orang anggota keluarga sejumlah $62(31 \%)$, dan lebih dari 3 orang anggota sejumlah 59 orang $(29,5 \%)$.

\section{Pola Perjalanan Wisatawan Milenial}

Wisatawan milenial yang datang ke Bali didominasi oleh wisatawan repeater (lebih dari 3 kali) datang ke bali sejumlah 75 orang (37\%). Hal ini menunjukkan bahwa mereka selalu tetap ingin datang ke Bali dan Bali masih menjati tempat yang eksis dan menarik untuk selalu dikunjungi. Lama tinggal wisatawan milenial di Bali (length of stay) didominasi oleh wisatawan dengan lama tinggal lebih dari 4 hari sejumlah 135 orang $(67,5 \%)$. Hal ini menunjukkan bahwa banyak aktivitas yang mereka lakukan selama berlibur di Bali. Orang yang paling sering diajak berkunjung ke Bali oleh wisatawan milenial lebih didominasi oleh berkunjung dengan keluarga sejumlah 90 orang (45\%), kemudian teman sejumlah 72 orang (36\%), terakhir Bersama pasangan sebanyak 38 orang (19\%).

Jenis transportasi yang digunakan untuk mencapai Bali lebih didominasi oleh pesawat terbang sejumlah 125 orang $(62,5 \%)$, dan yang paling sedikit adalah menggunakan sepeda motor sejumlah 24 orang (12\%). Jenis akomodasi yang ditempati oleh wisatawan milenial di Bali lebih didominasi oleh jenis akomodasi Hotel sejumlah 94 orang (45\%) sesuai dengan kenyamanan mereka untuk pemilihannya dan yang terendah adalah resort sejumlah 3 orang $(1,5 \%)$.
Lokasi akomodasi yang ditempati oleh wisatawan milenial di Bali didominasi oleh wilayah Kuta dan sekitarnya sejumlah 90 orang $(45 \%)$ dan lainnya sejumlah 41 orang (20,5\%) seperti: Tabanan, Denpasar, Ubud (Gianyar) dan Karangasem.

Pihak yang mengurus proses perjalanan wisatawan milenial di bali mereka lebih banyak memilih untuk mengaturnya sendiri tanpa bantuan travel sejumlah 100 orang (50\%). Adapun informasi yang wisatawan milenial dapatkan untuk tempat wisata di Bali sebagian besar didapat dari media sosial sejumlah 109 orang (54,5\%). Aktivitas yang paling sering mereka lakukan di Bali sebagian besar adalah melakukan selfie sejumlah 70 orang $(35 \%)$. Saat melakukan perjalanan wisata di bali wisatawan milenial lebih memilih moda transportasi mobil sewaan yang disetir sendiri sejumlah 49 orang $(24,5 \%)$ dan sepeda motor disetir sendiri sejumlah 48 orang $(24 \%)$.

\section{Pola Pengeluaran Wisatawan Milenial}

Adapun pengeluaran wisatawan dalam berwisata perhari lebih didominasi oleh jumlah kisaran kurang dari satu juta rupiah sejumlah 117 wisatawan milenial $(58,5 \%)$. Dimana dalam akomodasi mereka lebih memilih hotel seperti City Hotel yang kisaran harga tidak melebihi Rp.500.000., setiap harinya dan ada juga yang menginap dirumah teman atau keluarga mereka. Alasan wisatawan dalam pemilihan akomodasi adalah kenyamanan, kepercayaan terhadap akomodasi tersebut, serta harga yang lebih terjangkau, kemudian letak yang strategis, dan berdasarkan pada hasil pencarian informasi melalui lebih banyak menggunakan media sosial. Jika dilihat dari penilaian terkecil menunjukkan bahwa wisatawan tidak mau mengeluarkan biaya sebesar Rp.2.000.000 permalam hanya untuk menyewa sebuah akomodasi, wisatawan milenial juga tidak menggunakan perantara travel agent dalam pemesanannya melainkan langsung memesan keperluannya seorang diri.

Untuk pengeluaran Food and Beverage (makanan dan minuman) wisatawan milenial lebih banyak memilih pengeluaran yang kurang dari Rp. 350.000., perhari. Mereka lebih suka mencoba makanan khas Bali yang sedang trend di media sosial. Seperti warung makan "Men Weti", Pasar Senggol Gianyar, "Mak Beng" dan lain-lain. Hal ini terbukti bahwa persentase dari keseluruhan indikator 
dalam menilai pengeluaran wisatawan dalam makanan dan minuman, adalah sebesar $89 \%$ wisatawan milenial tertarik mencicipi makanan dan minuman tradisional/ Indonesia daripada makanan dan minuman dari daerah atau negara asal wisatawan tersebut, dengan harga yang lebih terjangkau, dan referensi dari tempat makan tersebut berasal dari media social dan yang menarik adalah dalam menu makanan dari restoran atau tempat makan tersebut sebesar 74,13\% menginginkan menu makan yang sehat. Hal ini menunjukkan bahwa wisatawan milenial dalam memilih tempat makan tetap mencari yang murah, tradisoinal, referensi dari media sosial namun tetap mengutamakan menu sehat.

Pengeluaran souvenir atau oleh-oleh wisatawan milenial rata-rata pada harga berkisar antara Rp.500.000,00 hingga Rp.1.000.000,00. Wisatawan milenial dalam pemilihan souvenir lebih memilih sesuai dengan manfaatnya dan lebih suka membelinya di pasar tradisional seperti pasar seni ubud, sukawati dan guwang. Jika dilihat dari persentase pada indikator pengeluaran wisatawan memilih souvenir berdasarkan harga yang lebih terjangkau sebesar (88\%), atas rekomendasi dari teman/keluarga, wisatawan milenial lebih memilih souvenir yang berupa barang seni yang utama bermanfaat untuk diri sendiri dan untuk oleholeh teman dan kerabat. Adapun jenis souvenir yang dipilih oleh wisatawan milenial lebih didominasi oleh barang seni dan makanan, karena dalam memilih souvenir wisatawan ini lebih menekankan pada manfaat dari barang tersebut sebesar (90\%).

Dapat diketahui bahwa dalam penggunaan moda trasnportasi oleh wisatawan milenial dalam melakukan kunjungan di Bali, wisatawan memiliki kriteria dalam pemilihan dimana yang utama adalah kenyamanan, keamanan, waktu dan cuaca saat berkunjung ke sebuah daya Tarik wisata, kemudahan dalam mencapai tujuan, rute yang ditempuh, lamanya perjalanan, dan fasilitas yang didapat dari kendaraan tersebut. Untuk biaya penyewaan moda transportasi oleh wisatawan milenial lebih didominasi oleh wisatawan yang mengeluarkan uang berkisar Rp250.000,00 Rp500.000,00 per hari untuk mobil sewaan dan sepeda motor dibawah harga Rp200.000,00. Adapun pemilihan transportasi mobil sewaan dan sepeda motor sewaan sangan mudah untuk didapatkan dan dikendarai sendiri dengan alasan supaya lebih bebas dan fleksible dalam penggunaan, waktu tempuh yang bisa mereka atur sendiri serta lebih aman dan nyaman jika dikendarai seorang diri.

Pengeluaran untuk sebuah atraksi wisata mereka keluarkan rata-rata pada harga berkisar antara Rp.250.000,00 - Rp.500.000,00. Adapun alasan dalam pemilihan atraksi berdasarkan manfaat dan pengalaman yang didapat sebesar $(89,5 \%)$, berdasarkan kesenangan, rekomendasi teman/keluarga, ulasan dari media sosial, serta berdasarkan harga tiket masuk. Adapun sebelum menuju ke Bali wisatawan milenial terlebih dahulu merencanakan daya tarik mana saja yang akan mereka kunjungi. Hal ini mungkin dipengaruhi oleh beberapa ulasan dari media sosial dan rekomendasi dari teman atau keluarga.

\section{SIMPULAN DAN SARAN Simpulan}

Pola perjalanan wisatawan milenial ke Bali adalah repeater guest atau wisatawan yang datang sudah lebih dari sekali, dengan perjalanan yang didominasi menggunakan pesawat terbang menuju Bali, wisatawan lebih memilih media sosial sebagai sumber informasi, lebih suka melakukan selfie pada daya tarik wisata, menggunakan kendaraan sewa yang dikendarai sendiri.

Pola pengeluaran wisatawan milenial, didominasi oleh akomodasi, souvenir, Atraksi, kendaraan sewa serta makanan dan minuman. Dimana dalam pemilihan akomodasi, atraksi dan makanan serta minuman lebih banyak dipengaruhi oleh media sosial yang menjadi sumber rekomendasi wisatawan milenial.

\section{Saran}

Untuk peneliti selanjutnya sebaiknya meneliti aktivitas wisatawan milenial yang berkunjung ke Bali sehingga kita akan tahu secara lebih spesifik mengenai pergerakan wisatawan milenial di Bali.

Untuk industri pariwisata terutama travel agent untuk membuat suatu strategi baru supaya bisnis di bidang pariwisata masih bisa berjalan dengan baik, untuk restoran mulai menawarkan sesuatu yang menarik dan tidak lepas dari khas Bali serta penyedia atraksi lebih membuat spot-spot baru yang mampu untuk lebih menarik minat berkunjung wisatawan tanpa harus merugikan lingkungan sosial masyarakat maupun alamnya. 


\section{Kepustakaan}

Anonim, Undang-undang nomor 10 tahun 2009 tentang Kepariwisataan.

Cohen, E. (1979). Rethinking the Sociology of Tourism, Annals of Tourism Research, 6(1), 18-35.

Moleong, Lexy J. 2002. Metode Penelitian Kualitatif. Bandung: PT. Remaja Rosdakarya.

Pitana, I. G. Dan P. G. Gayatri. 2005. Sosiologi Pariwisata. Yogyakarta: Penerbit ANDI.

Seaton, A.V, Bennet. 1996. Marketing Tourism Product. UK: Cengage Leaming.

Sugiyono 2007. Memahami Penelitian Kualitatif. Bandung : ALFABETA.

Peta pulau Bali http://berliyanto.com/wpcontent/uploads/2013/01/peta-pulaubali.jpgdiunduh pada Jumat, 19 Januari 2018, pk. 13.23).

www.etnikbali.com (diunduh pada hari Minggu, 21 Januari 2018, pk. 19.18) Time. Jurnal Travel Research, 24(1), 4244. 